\title{
DISPOSIÇÃO DE RESÍDUOS SÓLIDOS NO ENTORNO DA LAGOA DO SUMIDOURO, APA CARSTE DE LAGOA SANTA, MINAS GERAIS ${ }^{1}$
}

Luiz Eduardo Panisset Travassos ${ }^{2}$; Cláudio Manoel Uemoto Maia ${ }^{3}$; Cristiano Furst Costa ${ }^{4}$; Cynthia Pimenta Brant Moraes 5 ; Michele Rodrigues Araujo ${ }^{6}$. (1-Trabalho apresentado na disciplina de Hidrologia do Curso de Especialização em Gestão Ambiental de Resíduos Sólidos da Pontifícia Universidade Católica de Minas Gerais, 2-Geógrafo, Especialista em Gestão Ambiental de Resíduos Sólidos pela PUC/Minas, Professor das Faculdades Promove, luizpanisset@uol.com.br ,3-Geógrafo, Especialista em Gestão Ambiental de Resíduos Sólidos pela PUC/Minas, 4-Geógrafo, Especialista em Gestão Ambiental de Resíduos Sólidos pela PUC/Minas, 5-Bióloga, Especialista em Planejamento e Gestão Ambiental , Especialista em Gestão Ambiental de Resíduos Sólidos pela PUC/Minas, 6-Graduada em Geografia e Meio Ambiente, Especialista em Gestão Ambiental, Especialista em Gestão Ambiental de Resíduos Sólidos pela PUC/Minas)

\section{RESUMO}

O presente trabalho teve como objetivo avaliar os principais impactos ambientais relacionados com a atividade antrópica e a disposição inadequada de resíduos sólidos na região da Lagoa do Sumidouro, APA Carste de Lagoa Santa, MG, avaliando os impactos ambientais ligados aos resíduos que são jogados na Lagoa do Sumidouro e seu entorno, procurando identificar as atividades que mais contribuem ou contribuíram para este tipo de poluição. O trabalho baseou-se em uma revisão bibliográfica sobre o assunto, com duas visitas a campo para constatar os dados previamente levantados, com entrevista a moradores e turistas.

Palavras-chave: Impactos ambientais, carste, resíduos sólidos. 


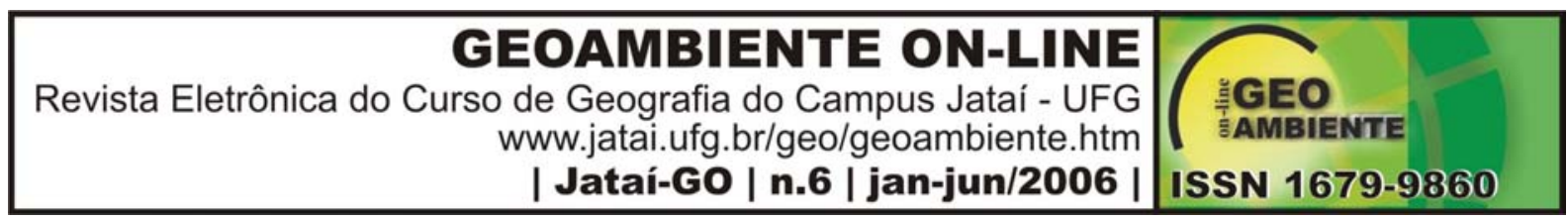

\section{ABSTRACT \\ SOLID WASTE DISPOSAL IN THE SURROUNDINGS OF THE LAGOA DO SUMIDOURO, APA KARST DE LAGOA SANTA, MINAS GERAIS - BRAZIL}

This paper aims the study and analysis of the main environmental impacts made by human activity in the surroundings of the Lagoa do Sumidouro, APA Carste de Lagoa Santa, Minas Gerais, evaluating the main impacts linked with the problem of inappropriate waste disposal in the region. The authors based the research on the study of previous Works in the region and two field trips to the site to compare and contrast the reality with the information previously read and interviews with locals and tourists.

Key words: Environmental impacts, karst, solid waste

\section{Introdução}

A região de Lagoa Santa está localizada no entorno da Região Metropolitana de Belo Horizonte, centro-sul do estado de Minas Gerais (Figura 1), constituindo um "importante exemplar de ambiente cárstico desenvolvido em rochas carbonáticas” (BERBERT-BORN, 2002, p.416).

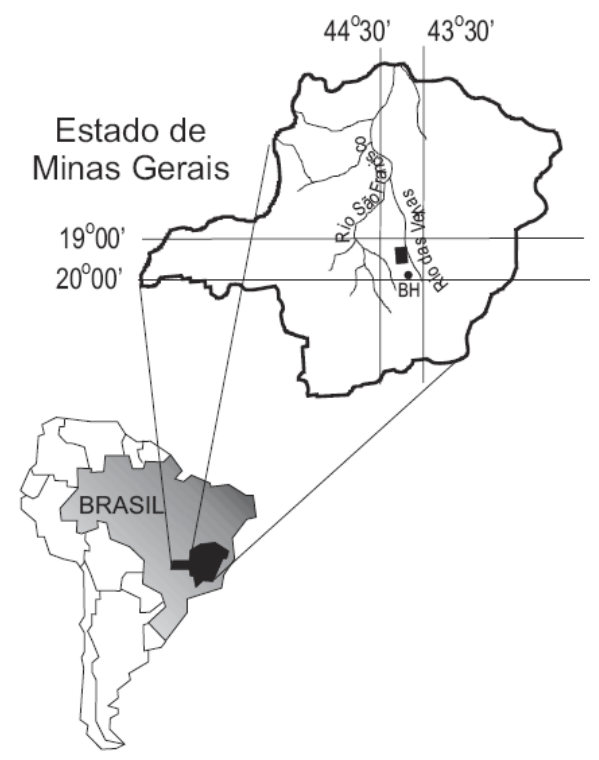

Figura 1 - Localização da APA Carste de Lagoa Santa (Fonte: BERBERT-BORN, 2002)

Inserida nessa região, encontra-se a Lagoa do Sumidouro, uma lagoa cárstica de grande relevância para a sobrevivência e manutenção da diversidade faunística da região, bem como 


\section{GEOAMBIENTE ON-LINE \\ Revista Eletrônica do Curso de Geografia do Campus Jataí - UFG www.jatai.ufg.br/geo/geoambiente.htm \\ | Jataí-GO | n.6 | jan-jun/2006 |

área de relevância acadêmica aos estudos geomorfológicos e dos recursos hídricos, visto que é uma das áreas cársticas do país que mais vêm sofrendo com a ocupação antrópica.

"O carste de Lagoa Santa também tem um significado especial para a história da ciência e da cultura do povo brasileiro. A região é considerada o berço da paleontologia, arqueologia e espeleologia. O pioneirismo das pesquisas é justificado, em princípio, por tratar-se da região do país onde atualmente se registra o maior número de cavernas por área. Essa aglomeração de grutas e abrigos guarda grande quantidade de fósseis pleistocênicos, entre eles a chamada megafauna extinta, e os vestígios mais importantes da ocupação humana pré-histórica no Brasil, que incluem painéis rupestres, utensílios e ossadas, cujos registros mais antigos são datados de aproximadamente 12.000 B.P." (BERBERT-BORN, 2002, p.416)

Assim, consideramos a APA Carste de Lagoa Santa como uma das poucas, senão a única região no mundo, que reúne em um só limite, importância arqueológica, paleontológica, espeleológica e também histórica, visto que bandeirantes paulistas também deixaram suas marcas na região em época colonial.

Segundo Berbert-Born (2002), a região vem sofrendo com a expansão demográfica e representa um pólo industrial e minerador de extrema importância econômica, situação que nos leva a um crescente comprometimento da água, vegetação, solo e relevo.

Devido a essa situação conflitante entre preservação e desenvolvimento, estabeleceu-se através do Decreto Federal n ${ }^{\circ}$ 98.881, de 25 de janeiro de 1990, uma Unidade de Conservação com atributo de Área de Proteção Ambiental, a APA Carste de Lagoa Santa, englobando os municípios de Lagoa Santa, Pedro Leopoldo, Matozinhos, Funilândia e Confins.

Miotto et al (2005), informam que a APA se insere no grupo de unidades de uso sustentável, cujo objetivo básico é compatibilizar a conservação da natureza com o uso sustentável de parcela de seus recursos naturais, sendo constituída de parcelas de terras públicas e privadas.

Em vista disso, o objetivo desse breve estudo foi o de avaliar os impactos ambientais na Lagoa do Sumidouro e seu entorno, procurando identificar as atividades que mais contribuem para a degradação ambiental desse ecossistema.

\section{Desenvolvimento}

A Lagoa do Sumidouro localiza-se sobre rochas carbonáticas, em ambientes cheios de "significado no âmbito natural/cultural, dignos de valorização e preservação" (PILÓ, 1999, p.50), sendo amplamente utilizados pelo homem ao longo de sua evolução histórica. 


\section{GEOAMBIENTE ON-LINE \\ Revista Eletrônica do Curso de Geografia do Campus Jataí - UFG www.jatai.ufg.br/geo/geoambiente.htm \\ | Jataí-GO | n.6 | jan-jun/2006

A região consta em relatos dos viajantes do século XVIII e XIX, com maior destaque dado a Peter Lund, que descreve inúmeros sítios paleontológicos, arqueológicos e espeleológicos, ao se fixar na região de a partir de 1833. "Nos estudos sobre a Gruta do Sumidouro, em 1843, Lund faz uma pioneira e clara interpretação sobre a origem e evolução do Carste de Lagoa Santa" (PILÓ, 2002, p. 16).

Além do estudo dos aspectos físicos da região, Lund se dedica a outros ramos da história natural, como a paleontologia e a arqueologia. Prous (2002) afirma que, num ano de seca excepcional (1843), ao escavar próximo à Gruta do Sumidouro, Lund encontrou vestígios de grandes animais extintos misturados com restos humanos e "demonstrando um excelente conhecimento das noções de geologia disponíveis na época e muita argúcia, Lund notou que, em sua maioria, estes restos ósseos não estavam em posição primária (ou seja, no lugar onde tinham sido depositados no momento da morte), mas tinham sido transportados pelas águas antes de serem depositados na gruta" (PROUS, 2002, p.50).

Sendo assim, se confirma o grande valor científico e cultural da APA Carste de Lagoa Santa que atualmente é largamente utilizada para a exploração mineral, com indústrias para a produção de cimento, bem como para utilização de águas subterrâneas para suprir a demanda pelo recurso.

Entre outros impactos, é preocupante o aproveitamento agrícola com o uso indiscriminado de fertilizantes e adubos que, através do escoamento superficial e percolação, atingem os cursos d'água superficiais e subterrâneos.

\footnotetext{
"Essas atividades, quando mal gerenciadas, podem gerar impactos ambientais adversos à qualidade dos ambientes cársticos, dentre os quais, alteração das rotas de drenagens subterrâneas, poluição de aqüíferos, erosão dos solos, depredação de cavernas e painéis rupestres, etc.”(PILO, 1999, p. 50)
}

Inúmeros autores consideram a região como um domínio extremamente frágil e peculiar, principalmente quando levamos em conta fatores que a colocam em posição diferenciada.

No carste, a questão hidrológica ocupa destaque. Naqueles com maior grau de desenvolvimento, a drenagem é principalmente criptorréica (subterrânea) onde, segundo Piló (1999), os cursos d'água superficiais foram capturados para sistemas integrados de condutos e passaram a atuar de forma similar a drenos subterrâneos para o transporte livre e altamente localizado da água. 


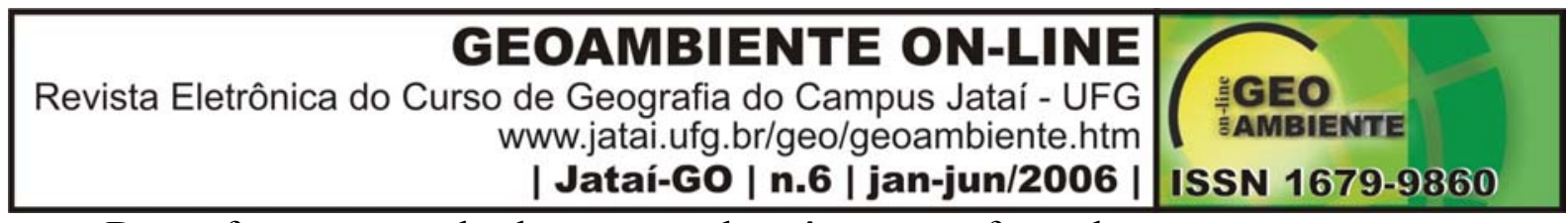

Dessa forma, rotas de drenagem subterrâneas são formadas e, por apresentarem um fluxo rápido, são mais susceptíveis às alterações ambientais.

“O fluxo mais rápido dessas drenagens potencializa a propagação muito mais rápida de possíveis poluentes que tenham atingido o aqüífero cárstico. Outro aspecto importante é que as bacias de drenagem, no carste, não se limitam necessariamente aos divisores de águas superficiais, podendo estender-se muito além desses limites".(PILÓ,1999, p.52).

Assim, impactos ambientais em áreas cársticas, quando relacionadas aos recursos hídricos, são muito menos pontuais. Processos de abatimentos podem ocorrer quando a água subterrânea é explorada de forma mais intensa e o assoreamento dos corpos d'água são comuns.

Já em 1837, Lund apontava a existência desses processos quando afirmava que "outro fenômeno ligado à riqueza da rocha calcária destas zonas é a desaparição súbita dos rios, que reaparecem em lugares mais ou menos distantes. A existência desses sumidouros originase da grande quantidade de fendas superficiais ou subterrâneas existentes na rocha" (LUND apud PILÓ, 2002, p.17)

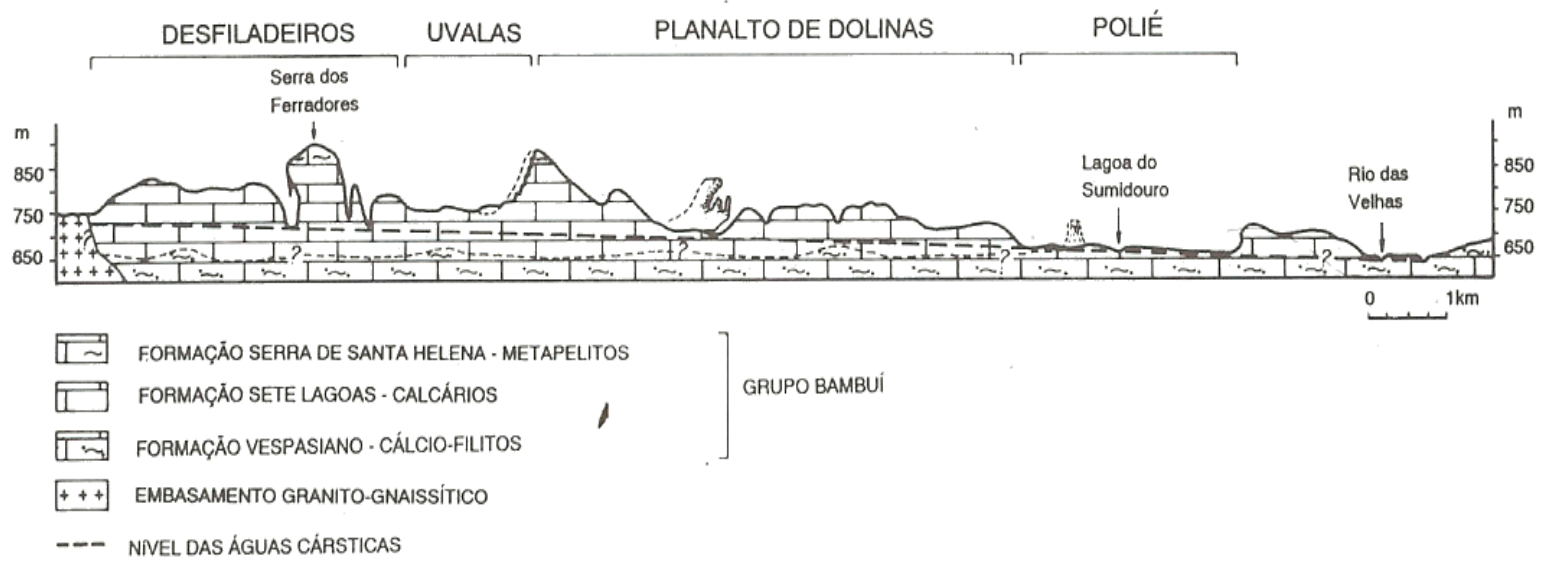

Figura 2 - Perfil topográfico, geológico e geomorfológico da APA Carste de Lagoa Santa MG (Fonte:GUERRA,1998).

\section{Localização da área de estudo}

A Lagoa do Sumidouro está localizada na APA Carste de Lagoa Santa, no entorno da Microrregião de Belo Horizonte do Estado de Minas Gerais, a margem esquerda do Rio das Velhas, podendo ser alcançada pela MG-424, no sentido Belo Horizonte - Pedro Leopoldo - 


\begin{tabular}{|c|c|}
\hline $\begin{array}{r}\text { GEOAMBIENTE ON-LINE } \\
\text { Revista Eletrônica do Curso de Geografia do Campus Jataí - UFG } \\
\text { www.jatai.ufg.br/geo/geoambiente.htm } \\
\text { | Jatai-GO | n.6 | jan-jun/2006 | }\end{array}$ & $\begin{array}{l}\text { (TGEO } \\
\text { ISSN } 1679-9860\end{array}$ \\
\hline
\end{tabular}

Matozinhos - Sete Lagoas, ou pela MG-010, no sentido Belo Horizonte-Lagoa Santa.

Essa área de proteção ambiental possui 35.600 ha, abrangendo os municípios de Lagoa Santa, Pedro Leopoldo, Confins, Matozinhos e Funilândia.

"As principais sub-bacias hidrográficas são definidas pelos córregos Samambaia, Palmeiras-Mocambo, Jaguara e riacho do Gordura (Figura 3), para onde são drenadas as águas pluviais em grande parte capturadas pelos inúmeros dolinamentos ao longo da área. Os limites dessas bacias ainda não estão perfeitamente reconhecidos, porque muitas rotas de fluxo subterrâneo ainda são desconhecidas. Todas elas têm descarga final ou no rio das Velhas a nordeste, ou no ribeirão da "

(BERBERT-BORN, 2002, p.4

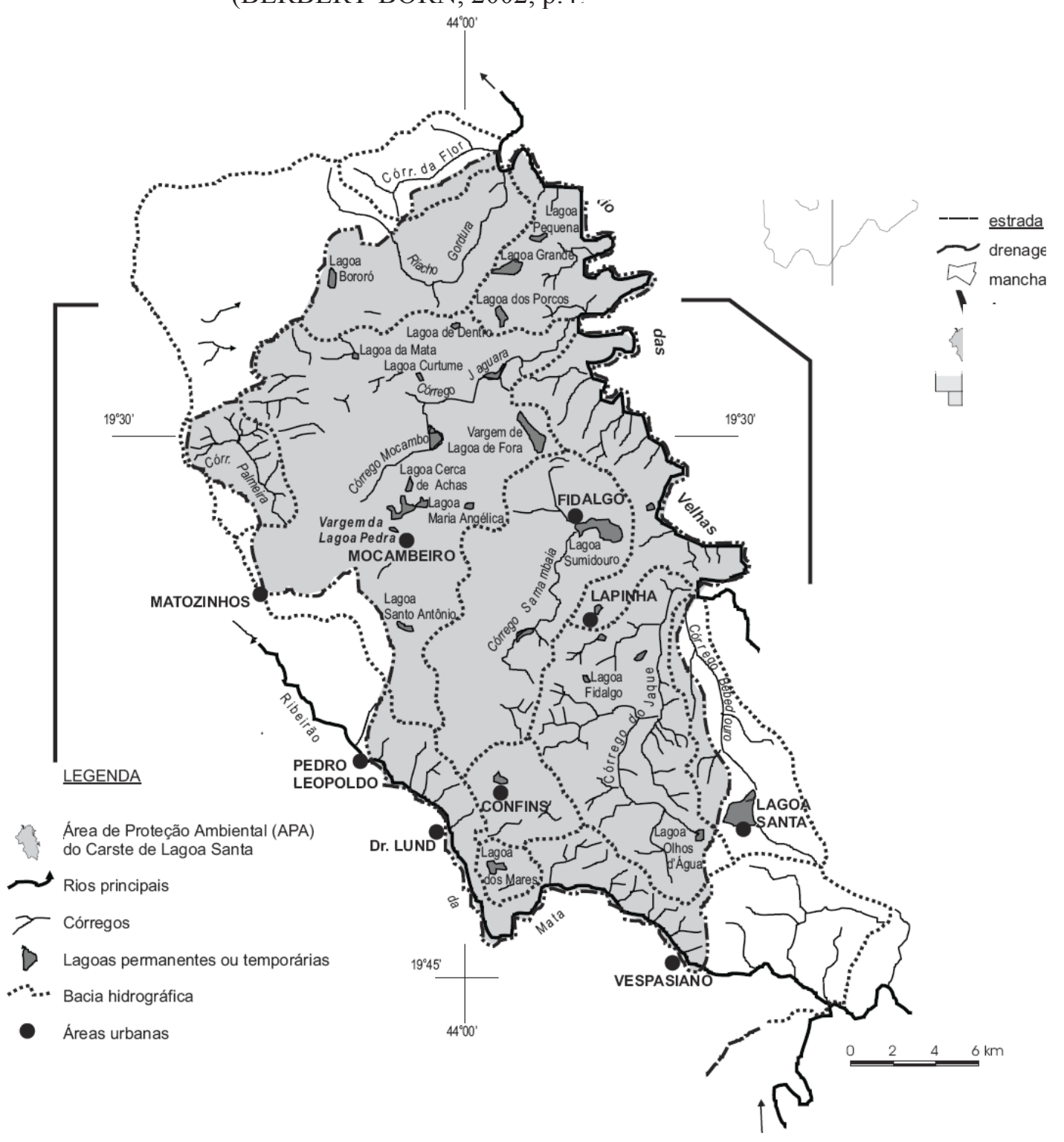

Figura 3 - Hidrografia da APA Carste de Lagoa Santa (Fonte: BERBERT-BORN, 2002) 


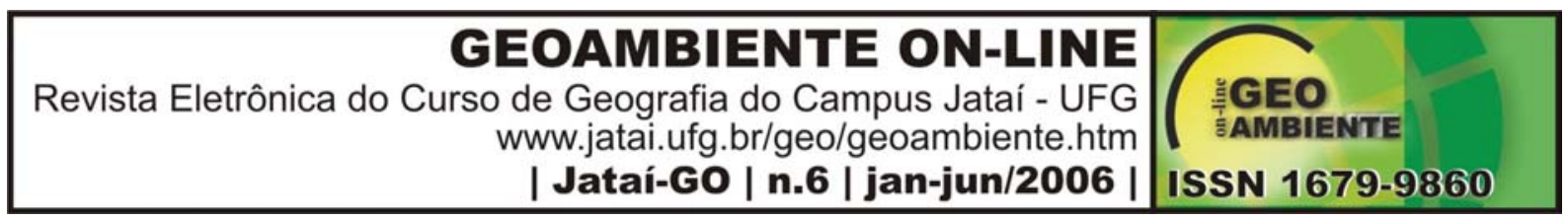

"A temperatura média do ar é da ordem de $23^{\circ} \mathrm{C}$.A umidade relativa varia de $60 \%$ a $77 \%$ nos meses mais secos e úmidos, respectivamente, chegando a $96 \%$ nos meses mais úmidos. A pluviometria média está em torno de $1380 \mathrm{~mm}$. O período seco estende-se por cinco meses, de maio a setembro, com menos de $7 \%$ das chuvas anuais, caracterizando um regime pluviométrico tipicamente tropical, havendo uma grande concentração de chuvas no verão e seca no inverno. A região possui formações vegetacionais de cerrado e floresta estacional semidecidual (IBGE,1993). O cerrado restringe-se a manchas remanescentes,em regeneração ou em transição (mata-cerrado). Nas dolinas e arredores dos afloramentos prevalece a Floresta Estacional Semidecidual. Sobre os afloramentos calcários desenvolve-se Floresta Estacional Decidual”.(BERBERT-BORN, 2002, p.418).

A Lagoa do Sumidouro tem grande importância para os moradores da região, principalmente os que residem na Quinta do Sumidouro. Para alguns visitantes, é apenas um referencial para a paisagem local; para outros, a lagoa faz parte da região, com destaque para feições do carste como por exemplo, a Lapa do Sumidouro.

As regiões cársticas são paisagens que despertam sentimentos diversos, principalmente àqueles relacionados às conotações negativas (quando tratamos do endocarste) e positivas (quando tratamos do exocartse). Assim, o uso mais comum da lagoa feito por moradores e turistas é a pesca e a natação.

\section{Impactos avaliados}

Piló (1999) afirma que a urbanização e a concentração de indústrias podem ocasionar vários tipos de problemas e impactos nos ambientes cársticos, como por exemplo, inundações, poluição dos corpos d'água, abatimentos induzidos, alteração nos sistemas hídricos subterrâneos e superficiais, poluição atmosférica e chuva ácida.

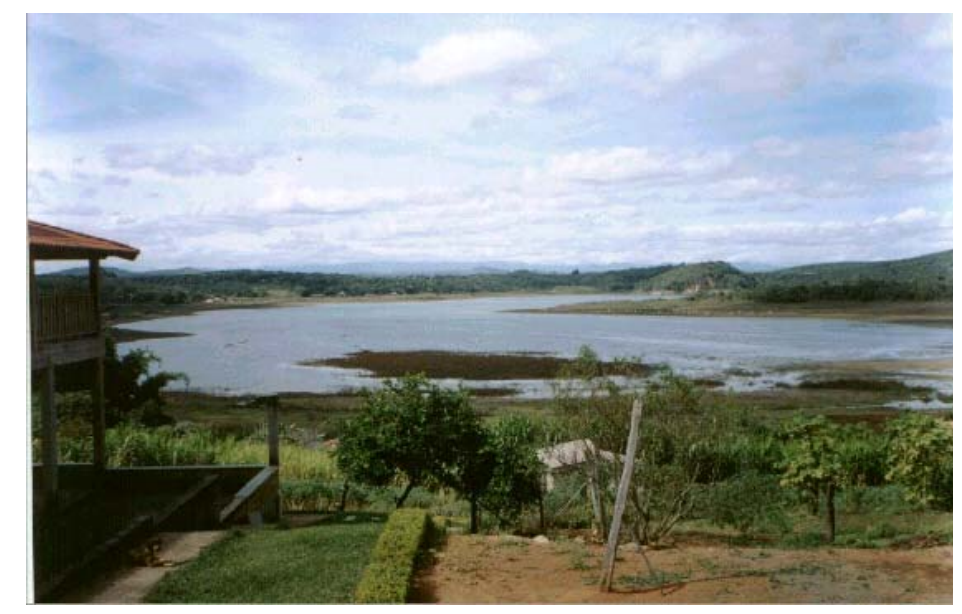

Figura 4 - Vista panorâmica da Lagoa do Sumidouro - Fidaldo/MG. (Foto: Aureliana Miguel Arcanjo e Júnia Joanes dos Santos, 2004) 


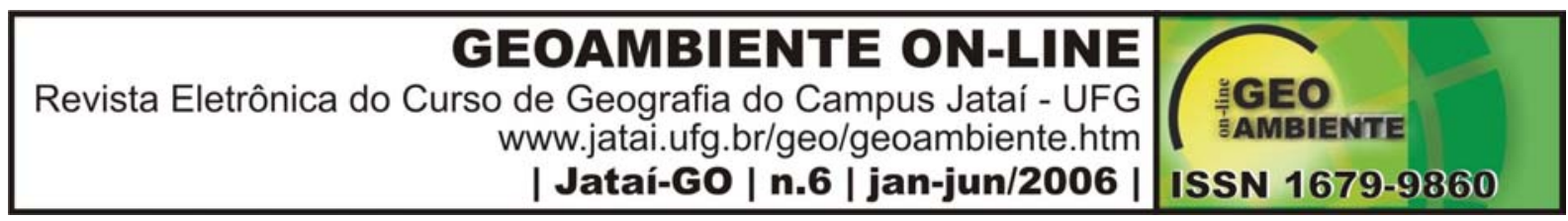

Os problemas mais comuns e também mais fáceis de serem observados no entorno da lagoa são o lixo deixado pelos turistas (Figura 05) e o uso e ocupação do solo no seu entorno.

O turismo é um dos fenômenos econômicos mais expressivos identificados nas últimas décadas. No entanto, independente dos impactos positivos que possam advir dessa atividade, não podemos esquecer dos impactos negativos que podem ocorrer nas comunidades receptoras, gerando assim, problemas sócio-ambientais que podem se ampliar comprometendo a qualidade de vida e o ambiente. "A falta de planejamento e gestão sustentáveis das áreas turísticas faz da visita uma aventura, colocando a conservação de importantes patrimônios aos desejos da sorte” (RUSCHMANN, 2003).

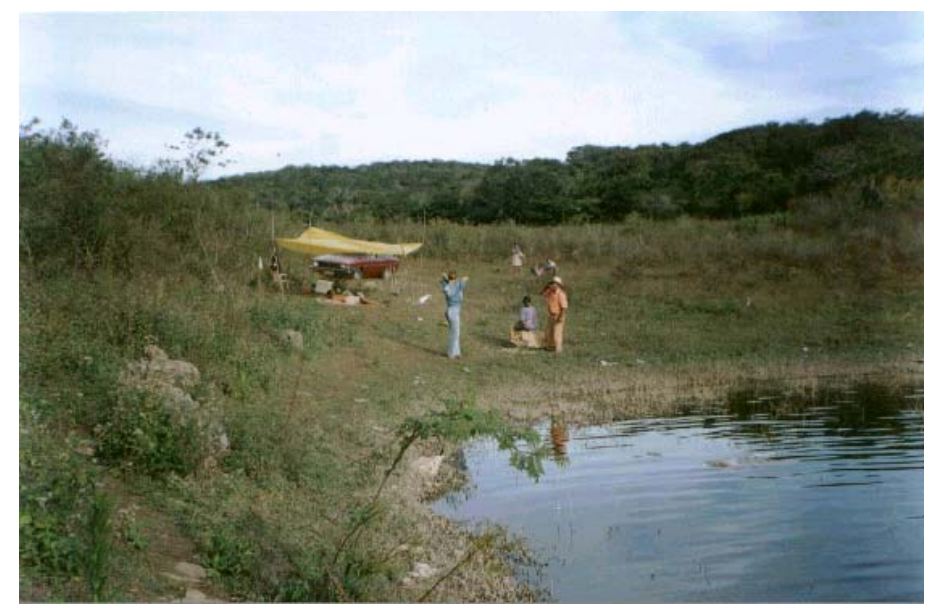

Figura 5 - Acampamento de turistas.(Foto: Aureliana Miguel Arcanjo e Júnia Joanes dos Santos, 2004)

Segundo entrevista realizada junto aos freqüentadores, a lagoa não é poluída. Muitos afirmam utilizar a Lagoa por muitos anos e nunca adoecerem. Contudo, se levarmos em conta a existência de plantações, cidades e indústrias no entorno, poderíamos ter a contaminação por parte de efluentes sanitários ou industriais sem tratamento, apresentando, segundo Pilo (1999, p.55) “fontes potenciais para a poluição dos aqüiferos cársticos”.

Para os moradores, a evidência da não poluição é a presença de peixes como as piabas, tilápias e as traíras (Figura 06), fato que sabemos não ser um método seguro nessa caracterização. 


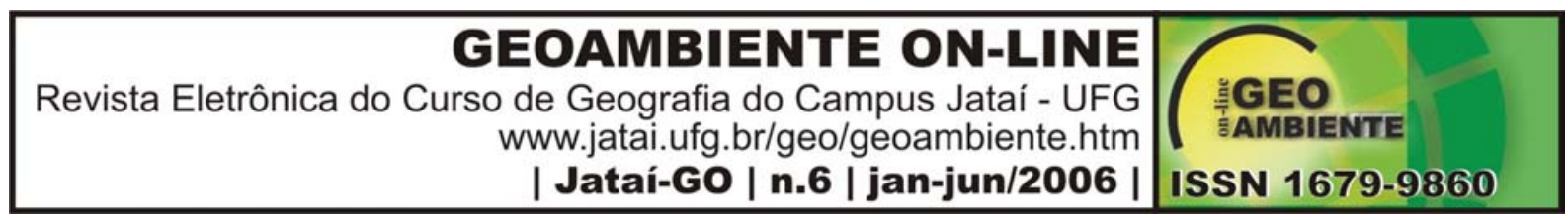

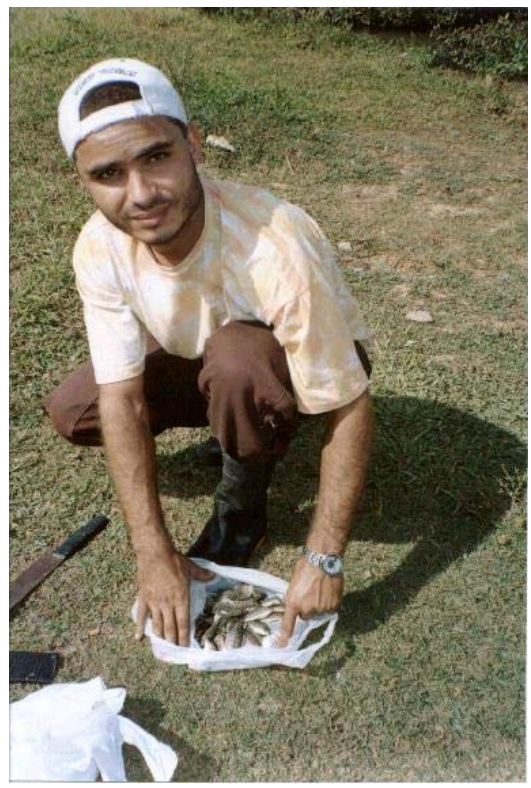

Figura 06 - Tilápias pescadas na Lagoa do Sumidouro - Fidalgo/MG. (Foto: Aureliana Miguel Arcanjo e Júnia Joanes dos Santos,2004).

Outro problema identificado é o assoreamento em alguns setores da lagoa. Acreditamos que esse processo se dá como conseqüência da deposição dos rejeitos do beneficiamento de pedreiras no entorno, bem como, do processo de preparo do solo para a agricultura (Figuras 07 e 08$)$.

\footnotetext{
"A falta de planejamento e de infra-estrutura na expansão urbana pode ocasionar o aumento dos processos erosivos e o assoreamento de corpos hídricos. A falta de um sistema eficiente de contenção de sedimentos, quando da instalação do conjunto habitacional São Camilo, certamente intensificou, juntamente com a mineração, o assoreamento da Lagoa Santo Antônio. Esta lagoa cárstica atingiu durante as fortes chuvas de verão de 1996/97, uma cota altimétrica muito acima do normal, inundando mais de 30 residências" (PILÓ, 1999, p.55).
} 


\begin{tabular}{|c|c|}
\hline $\begin{array}{r}\text { GEOAMBIENTE ON-LINE } \\
\text { Revista Eletrônica do Curso de Geografia do Campus Jataí - UFG } \\
\text { www.jatai.ufg.br/geo/geoambiente.htm } \\
\mid \text { Jataí-GO | n.6 | jan-jun/2006 | }\end{array}$ & $\begin{array}{l}\text { (ICEO } \\
\text { ISSN } 1679-9860\end{array}$ \\
\hline
\end{tabular}

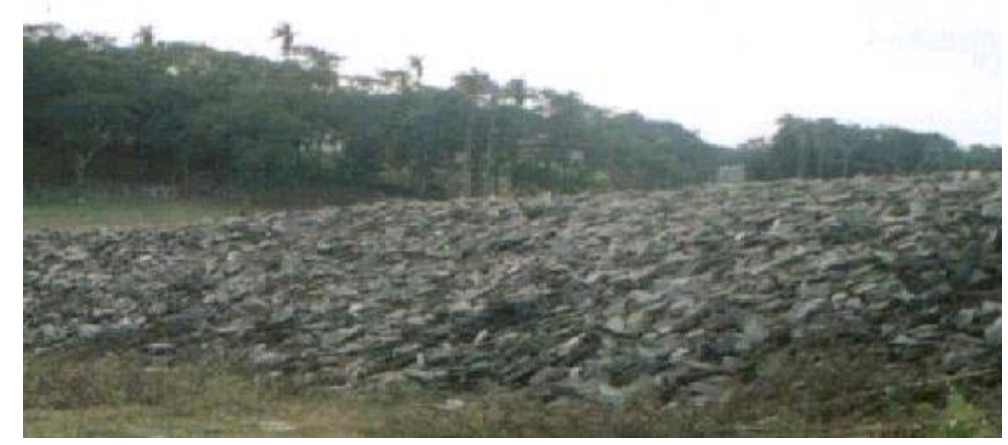

Figura 07 - Rejeitos das "pedreiras" no entorno da Lagoa do Sumidouro - Fidalgo/MG (Foto: Aureliana Miguel Arcanjo e Júnia Joanes dos Santos,2004)

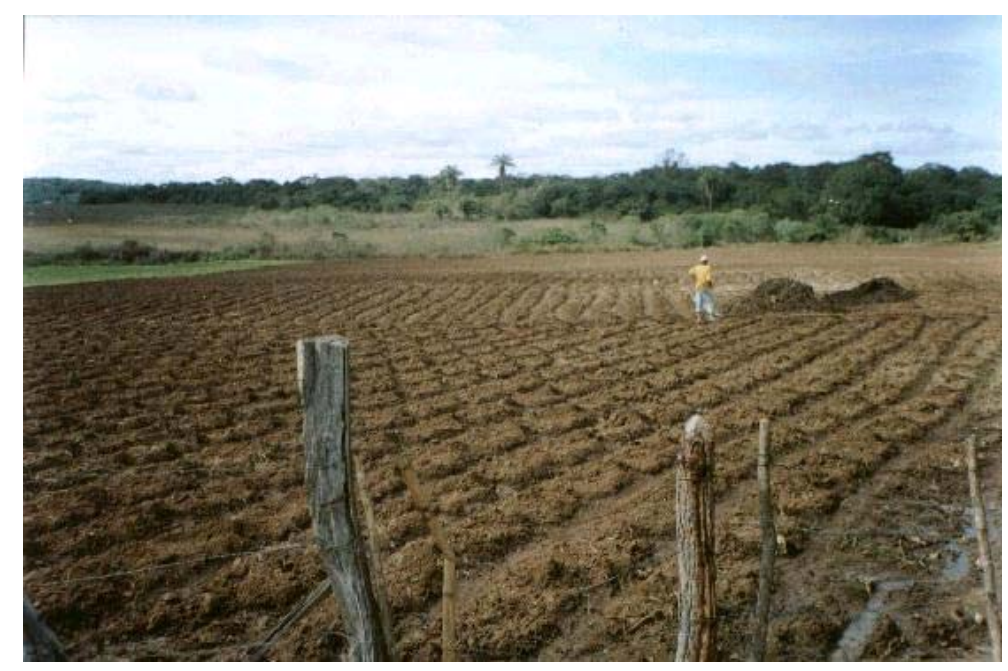

Figura 08 - Solo arado para agricultura - Fidalgo/MG. (Foto: Aureliana Miguel Arcanjo e Júnia Joanes dos Santos,2004)

Acredita-se que o maior problema da região está relacionado à presença dos turistas, que geralmente deixam lixo nas margens e, até mesmo, dentro da lagoa. Verificou-se que a maioria deles desconhecem a amplitude dos problemas causados pela deposição do lixo em sua orla (Figura 9), necessitando de um trabalho de educação ambiental na região.

Carcaças de animais mortos são ocorrências comuns na região devido à presença de pequenas propriedades rurais (Figura 10). 

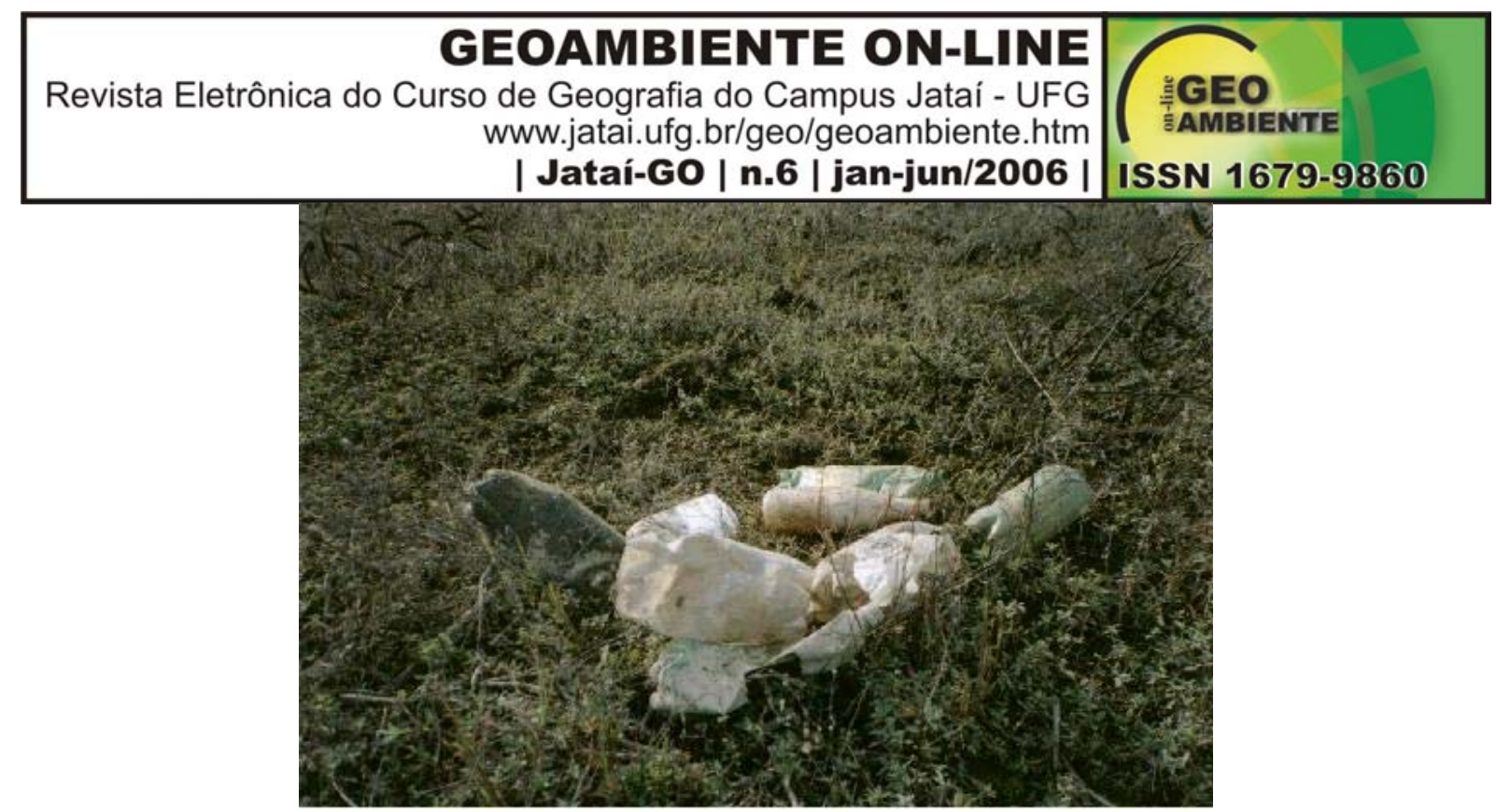

Figura 9 - Lixo no entorno da Lagoa do Sumidouro - Fidalgo/MG (Foto: Aureliana Miguel Arcanjo e Júnia Joanes dos Santos,2004).

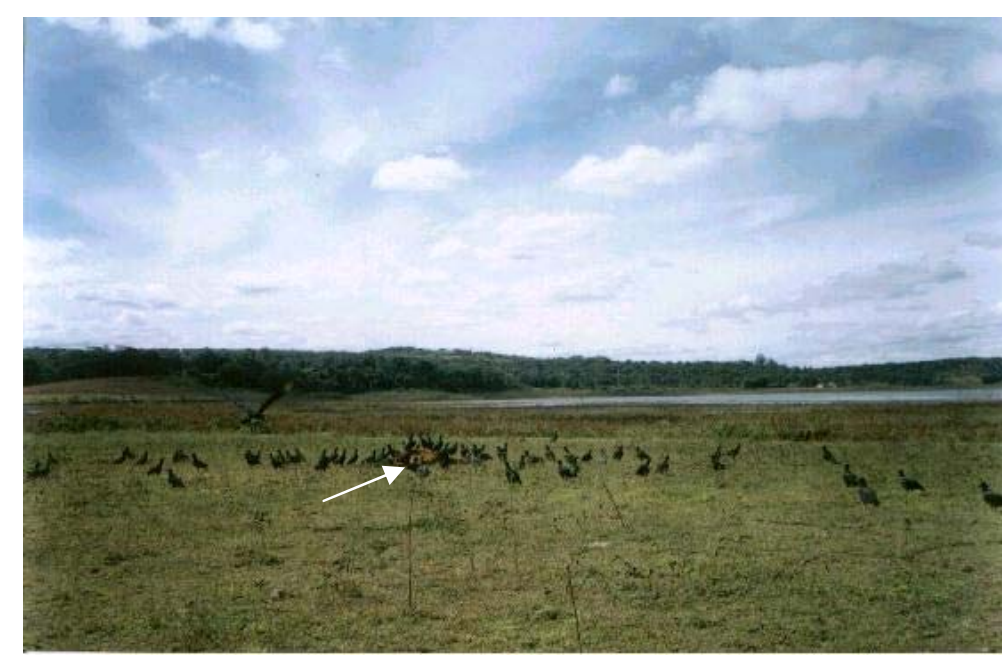

Figura 10 - Animal morto nas margens da Lagoa do Sumidouro - Fidalgo/MG (Foto: Aureliana Miguel Arcanjo e Júnia Joanes dos Santos,2004)

Outro problema levantado é o uso de fossas mal planejadas em algumas casas do entorno. Em sua maioria, são fossas sépticas, fundamentais no combate a doenças, verminoses e endemias, ao evitarem o lançamento dos dejetos humanos diretamente em rios, lagos ou na superfície do solo.

No entanto, esse tipo de fossa, se não construída de forma adequada, pode contribuir para a poluição do solo e água. Se levarmos em conta que esse tipo de recipiente é um simples tanque enterrado receptor de dejetos que retém a parte sólida e permite a percolação da parte líquida pelo solo, em uma região calcária cheia de fissuras e porosidades, pode ocorrer infiltração e a contaminação da água subterrânea. Acreditamos que a melhor solução para o 


\section{GEOAMBIENTE ON-LINE \\ Revista Eletrônica do Curso de Geografia do Campus Jataí - UFG www.jatai.ufg.br/geo/geoambiente.htm \\ | Jataí-GO | n.6 | jan-jun/2006 | \\ IGEO \\ AMBIENTE \\ ISSN 1679-9860}

problema seria a efetiva construção de uma rede de esgoto com suas respectivas estações de tratamento antes do lançamento nos corpos d'água.

\section{Conclusão}

Segundo Travassos (2002), a proteção e preservação dos cenários cársticos devem levar em conta os valores e interesses envolvidos para, a partir daí, serem estabelecidos programas de uso sustentável e ações de preservação. Essas ações, devem ser elaboradas com o intuito de poderem ser, ao mesmo tempo, quando possível, preventivas, mitigadoras e corretivas, de acordo com as exigências técnicas de gestão e manejo, reduzindo ao máximo, determinados efeitos e atividades que se apresentem responsáveis pela deteorização da paisagem, de forma direta ou indireta.

A atividade econômica predominante na área de estudo é representada pela extração mineral principalmente da pedra de Lagoa Santa. A população identificada é predominantemente de moradores antigos, sitiantes e turistas, sendo os responsáveis pela ocupação urbana da orla da lagoa.

Nas margens da lagoa encontraram-se resíduos gerados pelo turismo, rejeitos de mineração e restos de animais mortos. Os turistas mostraram-se preocupados com a fiscalização em torno da pesca e não com os impactos causados pelas outras atividades.

O controle da poluição provocada pelo turista está ligado à gestão ambiental e ao processo de tomada de decisão, onde faz-se necessário o envolvimento da sociedade nas suas diferentes formas de organização. A percepção dos freqüentadores da lagoa sobre a realidade ambiental e os problemas causados são fundamentos para elaboração de um plano mais eficaz de gerenciamento do turismo.

Custa caro para a comunidade a perda do potencial estético, turístico e o gasto com a limpeza da lagoa. Sabemos que é impossível anular a ação antrópica sobre o meio ambiente, mas para que se tenha o equilíbrio entre as partes, faz-se necessário sua regulamentação.

Devemos ter a Educação Ambiental como "um dos eixos fundamentais para impulsionar os processos de prevenção da deteorização ambiental e do aproveitamento dos direitos dos cidadãos a um ambiente saudável, (...) desempenhando função importante para a formação de uma atividade de responsabilidade e solidariedade entre as pessoas, que garanta a conservação e preservação do meio ambiente, através dos conhecimentos, com profundidade específica, ao público em geral, meios de perceber e compreender as relações dos diversos fatores biológicos, físicos e sócio-econômicos, cuja função no tempo e no espaço, será 


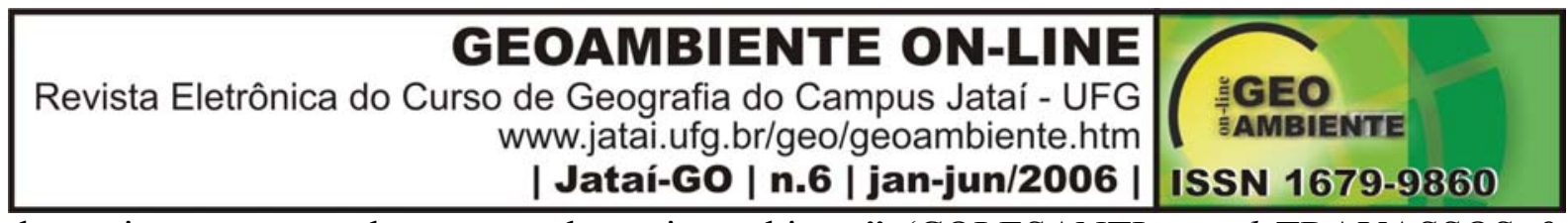

determinante para o bem estar do meio ambiente" (COLESANTI, apud TRAVASSOS \& TAVARES, 2004).

\section{Referências Bibliográficas}

ARCANJO, A.M; SANTOS, J.J. Impacto ambiental na Lagoa do Sumidouro. 2004. 63f.. Monografia (Conclusão de curso) - Uni-BH, Curso de Geografia e Analise Ambiental, Belo Horizonte.

BERBERT-BORN, M. Carste de Lagoa Santa, MG:Berço da paleontologia e da espeleologia brasileira. In: SCHOBBENHAUS,C.; CAMPOS,D.A.; QUEIROZ,E.T.; WINGE,M.; BERBERT-BORN,M.L.C. (Edit.) 2002. Sítios Geológicos e Paleontológicos do Brasil. DNPM/CPRM-Comissão Brasileira de Sítios Geológicos e Paleobiológicos(SIGEP)-Brasília 2002, 554p. p. 415 - 430. Disponível em: < http://www.unb.br/ig/sigep/sitio015/sitio015.pdf> .415 - 430. Acesso em: 3 jul. 2005.

MIOTTO, A.C.F. et al. Avaliação de desempenho ambiental na APA Carste de Lagoa Santa - MG: Em estudo de caso, 2004. 54f. Monografia (conclusão de curso) - Pontifícia Universidade Católica de Minas Gerais, Departamento de Geografia, Belo Horizonte.

PILÓ, L.B. Ambientes cársticos de Minas Gerais: Valor, fragilidade e impactos ambientais decorrentes da atividade humana. O Carste. Belo Horizonte, v.11, n.3, p. 50-58. Julho 1999. PILÓ, L B. P.W.Lund e a geomorfologia cárstica de Lagoa Santa. O Carste. Belo Horizonte, v.14, n.1, p. 12-17. Janeiro 2002.

PROUS, A. P.W.Lund e a arqueologia brasileira. O Carste. Belo Horizonte, v.14, n.1, p. 5051. Janeiro 2002.

RUSCHMANN, D.Turismo e Planejamento Sustentável: A Proteção do Meio Ambiente. Coleção Turismo - 10 edição, 2003

GUERRA, A.T.Geomorfologia: uma atualização de bases e conceitos. Rio de Janeiro: Bertrand Brasil, 1998. 472p.

TRAVASSOS, L.E.P. A percepção geográfica da paisagem cárstica como instrumento de preservação. Informativo da Sociedade Brasileira de Espeleologia. Campinas, n.82, 2002. 